\title{
A religião dos celulares: consumo de tecnologia como expressão de fé entre evangélicos e umbandistas
}

\section{Cell phones and their religions: technology consumption as an expression of faith among pentecostals and umbandistas}

Sandra Rubia da Silva ${ }^{1}$

Resumo Ao longo de 11 meses de trabalho de campo em um bairro de camadas populares em Florianópolis, pude constatar importantes conexões entre o consumo de telefones celulares e a vivência da religiosidade entre evangélicos e umbandistas. Neste artigo, exploro as maneiras pelas quais os telefones celulares estão presentes no discurso e nas práticas religiosas desses dois grupos, percebendo o celular tanto como mediador positivo quanto negativo. A partir da análise do material etnográfico, argumento que a associação entre religião e uso de telefones celulares, além de aliviar a experiência da pobreza, traz renovadas possibilidades de expressão da identidade religiosa. Sugiro também que a dimensão política está presente, na medida em que suas funcionalidades - em especial o bluetooth e o SMS - auxiliam na disseminação do discurso religioso e na obtenção de novos adeptos.

Palavras-chave: Telefones celulares; Bluetooth; Consumo; Evangélicos; Umbanda

Abstract This article explores the connections between cell phone use and religiosity in a low-income community in South Brazil. Drawing from ethnographic data collected through in-depth interviews and participant observation, it describes the new social and cultural practices that have arisen as a result of the integration of cell phones in the lives of Pentecostals and followers of umbanda,

\footnotetext{
${ }^{1}$ Universidade Federal de Santa Maria - UFSM, Santa Maria, RS, Brasil.

E-mail: sandraxrubia@gmail.com
} 
the most popular Afro-Brazilian religion. The article examines the dynamics and meanings involved in the process of social change that negotiates and brings together technology and religion in unique ways, particularly focusing on the role of bluetooth as a phone function that addresses social inequalities. It is suggested that cell phones not only enable new possibilities for the expression and practice of faith, but also, similarly to religion, empower community members, thus becoming an instrument that can help them cope with poverty.

Keywords: Cell phones; Bluetooth; Afro-Brazilian religions; Pentecostalism; Poverty 


\section{Consumo de tecnologia e objetificação de valores religiosos}

Quais são as relações entre a tecnologia, ${ }^{2}$ símbolo da modernidade fluida e acelerada da sociedade conectada, e a religião, caracterizada por dogmas e rituais ancestrais? Para pensar essa relação, é preciso perceber primeiro que, embora pareçam imutáveis, as religiões se reinventam de tempos em tempos, adicionando novos elementos.

Os estudos sobre as religiões afro-brasileiras de Prandi (2005) e Silva (1995), assim como as análises do pentecostalismo realizadas por Mariz (1994) e Mariano (1999), mostram que as religiões estão em constante mudança: transformam-se para se adaptar às novas demandas da sociedade, podendo, desta forma, competir de forma mais eficaz no crescente mercado religioso. Neste artigo, argumento que faz parte dessa dinâmica de transformações a inserção da tecnologia na vivência da religiosidade. Penso que uma boa chave explicativa para a compreensão do grande interesse de evangélicos e umbandistas por telefones celulares no morro S. Jorge, comunidade carente onde pesquisei, é fornecida por Mariz (1994): tal como a religião, os telefones celulares aliviam, em certa medida, o sentimento de impotência e abandono comum na experiência da pobreza. ${ }^{3}$

Embora considerável literatura sobre o uso de telefones celulares tenha florescido nos últimos anos (MILLER; HORST, 2006), muito pouco foi escrito a respeito de sua inserção nas práticas e na vivência da religiosidade. Nesse sentido, é pioneiro o trabalho de Campbell (2006). A autora argumenta que os telefones celulares empoderam os fiéis na medida em que se tornam instrumentos que possibilitam a integração das práticas religiosas ao estilo de vida frenético da contemporaneidade. Entretanto, existem tensões, controvérsias e contínua negociação

\footnotetext{
2 O termo "tecnologia", embora obviamente recubra diversas possibilidades, será, ao longo deste artigo, utilizado no sentido de "tecnologias de comunicação e informação".

${ }^{3}$ Nas palavras da autora: "Religion can be an important instrument in coping with poverty because it destroys poor people's experiences of being powerless. This sense of powerlessness is common among the very poor, and most religions strive to overcome it with the belief in spiritual power and the possibility of performing miracles" (MARIZ, 1994, p. 143).
} 
nesse processo de construção social da tecnologia, como Campbell ilustra por meio da análise do surgimento do celular "kosher" entre os judeus ultraortodoxos de Israel. O aparelho "kosher" (palavra que significa "aprovado pela lei religiosa") traz um selo especial da operadora de telefonia que atesta que foram desabilitadas funcionalidades consideradas ofensivas ${ }^{4}$ à religião, por possibilitarem acesso a conteúdo profano: acesso à internet, correio de voz e envio de mensagens de texto e de vídeo. Campbell utiliza o conceito de "tecnologias culturais" (cultured technologies), desenvolvido pelos cientistas políticos Barzilai-Nahon e Barzilai (2005), para entender o processo pelo qual uma comunidade ressignifica dada tecnologia, tornando-a parte de sua cultura. Entretanto, entendo que tal abordagem, embora possa ser frutífera, ignora todo um campo de estudos que, nas Ciências Sociais, tem se preocupado com as relações entre comunicação e cultura: a antropologia do consumo. Esta percebe que o consumo é uma prática cultural que vai muito além do momento da compra; portanto, trata-se de um processo dialético no qual objetos e sujeitos, mercadorias e pessoas, constituem-se mutuamente (APPADURAI, 1986, 1998; MILLER, 1987).

É nesse sentido que Miller propõe o conceito de objetificação como chave explicativa para o entendimento do consumo, em especial nas sociedades moderno-contemporâneas. Afirmar que o consumo é um processo de objetificação significa dizer que os agentes sociais usam os bens e serviços de tal forma que o objeto ou atividade "torna-se simultaneamente uma prática no mundo e uma forma na qual construímos nossos entendimentos acerca de nós mesmos no mundo" (MILLER, 1995, p. 30). Assim,a objetificação é uma proposta de abordagem às sociedades modernas que, distanciando-se de Marx e do fetichismo da mercadoria, considera o consumo um processo com grande potencial desalienante. Nas palavras do autor, "como atividade, o consumo pode ser definido como aquela que transfere o objeto de uma condição alienável, ou seja, a de ser um símbolo de estranhamento e valor monetário,

${ }^{4}$ Em seu estudo etnográfico sobre o uso de telefones celulares na Jamaica, Horst e Miller (2006) observaram uma prática relacionada ao uso religioso do celular entre pentecostais: a interdição dos ringtones seculares, considerados ofensivos, e sua substituição por ringtones "cristãos". 
para a de ser um artefato investido de conotações particulares e inseparáveis" (1987, p. 190). A afirmação do potencial desalienante do consumo é preciosa para o argumento que propusemos antes, qual seja, a de que o consumo de telefones celulares empodera os habitantes do morro S. Jorge em sua relação com a religiosidade e, assim, alivia sua experiência com a pobreza.

Para Miller (1987), que desenvolve seu conceito de objetificação a partir de Hegel, um entendimento mais profundo do lugar das mercadorias na sociedade requer necessariamente uma perspectiva do relacionamento entre pessoas e coisas. O significado do objeto é importante, mas não separado de sua dimensão material: esta deve ser levada em consideração para o entendimento dos motivos que tornam os objetos significativos para as pessoas. Consumindo, os agentes sociais objetificam valores como modernidade e sucesso, por exemplo, ou valores culturais relativos a categorias como classe, etnia e gênero (MILLER, 1987). O objetivo deste artigo é descrever os valores culturais relativos à religião que são objetificados através do consumo de telefones celulares entre os evangélicos e umbandistas do morro S. Jorge.

\section{"Porque o Senhor sabe como trabalhar": os telefones celulares no cotidiano dos evangélicos}

O morro S. Jorge, ${ }^{5}$ onde foi feita a etnografia para minha tese de doutorado, é uma comunidade de baixa renda na cidade de Florianópolis, no Sul do Brasil, onde vivem em torno de três mil pessoas, a maioria crianças e jovens. Em 2007, após uma primeira fase do trabalho de campo, de caráter exploratório, escrevi um artigo no qual apresentava esses primeiros resultados, constatando que os telefones celulares representavam uma parte importante da ideia de "ser moderno": seu uso constituía uma forma de "estar no mundo" mediada pela tecnologia, que é característica da cultura contemporânea (SILVA, 2008). Naquela altura, a

\footnotetext{
5 Optei por utilizar um nome fictício para a localidade, e também meus interlocutores são designados por pseudônimos. O material etnográfico foi obtido por meio de observação participante e entrevistas em profundidade. As imagens apresentadas neste artigo são de minha autoria.
} 
questão da religiosidade e dos telefones celulares não foi percebida por mim de forma explícita, embora estivesse presente no discurso de uma de minhas interlocutoras. ${ }^{6}$

Em julho de 2008, retornei ao campo de pesquisa com um olhar mais atento para essas questões. Descobri que Vânia, uma de minhas primeiras interlocutoras, começara, dois meses antes de nossa primeira entrevista, em janeiro de 2007, a frequentar os cultos da Igreja Universal do Reino de Deus que aconteciam no Templo Maior, no centro da cidade. À medida que o trabalho de campo avançava, era cada vez mais evidente a importância da religião para as pessoas do morro S. Jorge. Sediadas na própria comunidade há duas igrejas católicas, três templos da Assembleia de Deus e cerca de 10 terreiros de umbanda e candomblé (destes últimos tratarei mais adiante). Entre meus interlocutores, uma minoria era católica praticante; a grande maioria era evangélica (da Assembleia de Deus) ou umbandista, sendo que vários se declararam "católico-umbandistas".

Fiz amizade por acaso com um casal da Assembleia de Deus que adorava telefones celulares: Saulo, vigilante, e Edinéia, dona de casa, ambos na faixa dos 30 anos. Moram no alto do morro em uma casa de madeira em precárias condições, sem forro, cujo assoalho está apodrecendo rapidamente. Têm um casal de filhos adolescentes e vários jovens que vivem agregados à família, a quem chamam de "filhos na fé". Ao me conhecer e saber de minha pesquisa, Saulo se ofereceu para passar um "louvor" (música gospel) para o meu celular pelo bluetooth. Quando Saulo se tornou pastor, comecei a frequentar os cultos como observadora - não todas as segundas, quartas, sextas e sábados, como meus interlocutores, mas sempre que possível. Embora expressasse meu respeito por sua crença, eu reiterava que estava ali como pesquisadora

\footnotetext{
${ }^{6}$ Agradeço ao prof. Daniel Miller, do Departamento de Antropologia do University College London, a sugestão de explorar mais profundamente as relações entre consumo de telefones celulares e religiosidade.

${ }^{7}$ Mariz (1994) e Prandi (2005) lembram que esse comportamento pode ser explicado pelas condições de constituição histórica da umbanda no início do século XX - seu sincretismo com a religião católica, em uma época em que ser brasileiro passava obrigatoriamente por ser católico. Além disso, muitos umbandistas também frequentam a Igreja.
} 
e explicava meus interesses de pesquisa, que incluíam tanto as práticas dos evangélicos quanto as dos umbandistas. Porém, achei importante que meus interlocutores preferenciais, Saulo e Edinéia, soubessem que eu também frequentava cultos afro-brasileiros em função da pesquisa, o que foi respeitado. Isso não impediu que tentassem me fazer "aceitar Jesus” algumas vezes. Na congregação, encontrei Magda, irmã de Edinéia, e seu esposo Josevaldo. Indo aos cultos, frequentando suas casas, convivendo com suas famílias e vários de seus "irmãos da igreja”, pude descobrir algumas das formas pelas quais os telefones celulares se integram à vivência religiosa e ao discurso dos evangélicos.

Em primeiro lugar, há uma crença no poder absoluto de Deus, que age em benefício dos fiéis de várias maneiras. Esse ponto já estava presente no discurso de Vânia, que acredita que Deus agiu - porque "para Deus, nada é impossível" - para que sua patroa lhe desse um celular de presente. Para os pentecostais, o poder de Cristo é panaceia para todos os males terrenos (MARIANO, 1999) e o telefone celular, presente na vida cotidiana de seus fiéis, torna-se um de seus instrumentos. "O celular é uma invenção de Deus”, garante Edinéia. Ao final de um estudo bíblico no templo, ouço dona Martinha, a líder do grupo, contar para suas irmãs de igreja o seguinte episódio:

Irmãs, saibam que o Senhor, na Sua sabedoria, sempre encontra um jeito de chegar até nós. Vejam o que aconteceu comigo. Vocês sabem, quando eu estava doente eu não podia vir aos cultos. Mas meu marido e meus filhos vinham sempre. E eu estava uma noite em casa, com meu joelho inchado, com muita dor, sozinha, e sem ter ninguém perto. Eu estava precisando muito de uma palavra e pedi ao Senhor para alguém orar por mim. Nisso o meu celular toca, eu atendo e ninguém fala! E eu sem entender nada, com aquela dor... Mas aí eu presto atenção e escuto os louvores, e depois a voz do irmão Saulo pregando. Deus agiu através do celular para que eu estivesse no culto aqui com vocês. Deus agiu fazendo o celular do meu marido ligar para mim, e ele sem saber de nada. Porque ele chegou em casa e eu perguntei, "Tu ligou para mim, sabia"? E ele disse que não, o celular ficou o tempo todo no bolso. Mas eu disse para ele: "Deus agiu para aliviar a minha tribulação". Ele fez o celular apertar o botão da discagem rápida, tem o meu número armazenado. Isso é porque 
o Senhor sabe como trabalhar. Só para vocês verem o poder que Ele tem na nossa vida.

Se "o Senhor sabe como trabalhar" por intermédio do telefone celular, seus fiéis certamente também encontram formas muito interessantes de incorporar os celulares à sua prática religiosa. É o caso da corrente de oração que Edinéia realiza todos os dias com sua família e agregados, de manhã e à noite. Quando Saulo está trabalhando, acompanha e participa pelo celular. É importante que isso aconteça porque, como chefe de família, ele é o líder, explica-me Edinéia: "A gente liga para o número dele e deixa o celular no viva-voz, em cima da cama. Ele escuta a gente, e quando chega a vez dele, ele levanta a voz em oração e ora pelo telefone". Além disso, segundo Edinéia, quando um "filho na fé" seu está em Palhoça (cidade próxima na qual moram outros familiares), também participa da corrente de oração usando o celular no viva-voz. Essas correntes de oração duram, em média, meia hora, e Edinéia aproveita o fato de os celulares da família serem da mesma operadora para fazer ligações de graça, utilizando bônus promocionais: "Mês passado, comprei $\mathrm{R} \$ 35,00$ de créditos e ganhei mais de $\mathrm{R} \$ 400,00$ em bônus. $\mathrm{E}$ gastei tudo".

Os bônus promocionais são importantes para aliviar a pressão econômica advinda do fato de Edinéia e Saulo terem de estar sempre disponíveis para ajudar espiritualmente os residentes do morro S. Jorge, sejam eles evangélicos ou não. $\mathrm{O}$ aconselhamento espiritual por telefone faz parte da rotina do casal: "A gente ajuda as pessoas e já mostra para quem é ‘do mundo’ o caminho da salvação do Senhor”, diz Saulo. A maior parte são ligações recebidas, mas, dependendo da gravidade do caso, ambos fazem chamadas do celular: "Quando é de outra operadora, por amor a Deus a gente liga”. Edinéia está sempre com dois celulares e duas baterias, pois não pode ficar incomunicável ("tinha três celulares, um agora eu dei para minha filha”); o marido, também. Ambos recebem várias ligações por dia de pessoas pedindo orações e ajuda: 
O Saulo atende celular até no banho, deixa no viva-voz e vai falando com a pessoa. Quando minha filha na fé estava ganhando meu neto, até no hospital me ligavam. Eu atendo muitas pessoas no morro, muitas senhoras. Quase nunca paro em casa, por isso desisti de telefone fixo. Tem vez de ligarem meia-noite pedindo ajuda porque o esposo tá quebrando tudo em casa, porque tá na droga. E a gente, como servos de Deus, tem que atender.

Uma importante via de ligação dos evangélicos com o sagrado está na música. Os cultos a que assisti eram, na maior parte, cantados, interrompidos apenas pelas pregações; e havia nas igrejas corais organizados. $\mathrm{Na}$ maior parte do tempo, Saulo usa seus celulares com fone de ouvido - escuta seus hinos e louvores sempre que pode; a música nos fones é apenas interrompida quando há chamadas. Celulares de evangélicos são, na imensa maioria dos casos, espaços interditos para a chamada música "do mundo": no caso da paisagem musical do morro S. Jorge, trata-se principalmente do rap e do funk. Como são poucos os membros da Assembleia de Deus que têm acesso à internet na comunidade, a função bluetooth dos telefones celulares cumpre um importante papel na disseminação do discurso religioso presente nos hinos e louvores - quem tem acesso, baixa hinos da internet e compartilha via telefone celular. É comum a prática de trocar não somente hinos, mas também imagens antes do início e no final dos cultos. Entretanto, não se trata, aqui, de pensar em imagens que representem santos, o que, para os evangélicos, é considerado idolatria. As imagens nos celulares dos evangélicos exaltam a fé na figura de Jesus. Um exemplo está no papel de parede do novo celular de Saulo, que antes pertenceu a uma amiga do casal; a imagem mostra um grande coração vermelho no centro do qual está a palavra "Jesus".

Há outras maneiras, mais pragmáticas e menos simbólicas do que as imagens de louvor a Jesus e os hinos, pelas quais os celulares se integram às práticas religiosas através de suas funcionalidades. No caso de Saulo, seu outro celular, em cuja memória há mais de 20 louvores gravados, foi de muita valia quando o equipamento de sua igreja falhou, apenas uma 
semana após sua posse como pastor. Saulo não teve dúvidas - adaptou um microfone a uma caixa de som e usou seu celular para oficiar o culto e auxiliar a performance do coral. E o celular ajudou a celebrar o culto por muitas semanas na pequena igreja de $30 \mathrm{~m}^{2}$ até que fosse recolhido entre os fiéis dinheiro suficiente para consertar o equipamento de som.

Nesse ponto, vale a pena ressaltar que o espaço do templo, incluindo o momento do culto, não é interdito aos telefones celulares. A partir do momento em que este se configura como um "celular evangélico", em oposição a um "celular do mundo", por meio do controle de seus conteúdos e de seu uso, não é considerado profano e, portanto, impróprio no espaço do sagrado. O mesmo acontece com as câmeras digitais dos celulares. Ao contrário da Igreja católica, por exemplo, onde tirar fotos durante uma missa não é bem-visto, não é raro ver fiéis tirando fotos ou mesmo filmando durante as pregações - muitas vezes, vários ao mesmo tempo, durante o mesmo momento do culto.

Na tarefa de disciplinar o celular para que ele seja "evangélico", a palavra do pastor é fundamental. Além do cuidado com os conteúdos, nas ligações também é preciso usar o celular de acordo com os preceitos cristãos. "O celular pode ser uma arma do diabo na mão de uma pessoa”, afirma Saulo. Edinéia me revela que a temática do uso do telefone celular já se fez presente em mais de uma pregação. Nesse sentido, ele é visto pelos evangélicos do S. Jorge como um mediador negativo, principalmente em questões relacionadas ao endividamento, à fofoca e à maledicência.

Sim, toda sexta é dia de pregação de disciplina. E o pastor deu uma nota, uma vez, assim, o celular tem que saber usar. Se faz uma conta, tem que ter a responsabilidade de pagar a conta. Não usar o celular para ligar e falar coisas erradas, fazer fofoca, brigar, não falar alto no telefone, usar o telefone para passar uma mensagem de fé, de amor, de esperança, não para coisas erradas.

A própria Edinéia teve um problema recente em família relacionado a essa questão. Começou a receber ligações de algumas crianças e adolescentes que diziam que Saulo era seu pai e que as havia abandonado. 
Começaram a desconfiar de um sobrinho de 15 anos que andava meio rebelde - ele teria dado o número da tia por ter levado uma bronca. "Aí a gente passou um hino para o celular dele - aquele mesmo que a gente passou para ti, Sandra. Lembra? Não deu outra. No dia seguinte ele foi ao culto, os olhinhos marejados, confessou e pediu desculpas."

Para passar "uma mensagem de fé", os evangélicos se apropriaram da função SMS do celular: mandam trechos da Bíblia por mensagem de texto. "A mensagem é conforme o momento que a pessoa está passando", afirma Magda, irmã de Edinéia. Embora não seja grátis, como o bluetooth, envolve um custo relativamente baixo - em torno de R \$ 0,35 o torpedo. Um dirigente da Assembleia de Deus, Josevaldo, concunhado de Saulo, revela-me enviar cerca de 10 mensagens por semana e receber outras tantas. Ele me explica que já conseguiu pessoas “do mundo" para a igreja com os torpedos: "Quando a mensagem é para alguém da igreja, a gente passa só o capítulo e número do versículo. Quando é uma pessoa que não conhece a Bíblia, a gente digita o versículo inteiro”.

Assim, as variadas formas pelas quais os telefones celulares são apropriados pelos evangélicos em sua vivência da religiosidade expõem sua visão de mundo e reforçam a performance de identidade religiosa entre os membros do grupo. Igualmente, ao atuar como instância de disseminação do discurso religioso, o consumo de telefones celulares cumpre uma função política - "política", aqui, tomada no "sentido amplo de relações, assunções e competição relacionadas ao poder" (APPADURAI, 1986, p. 57) - auxiliando na obtenção de novos adeptos para a Assembleia de Deus.

\section{“Meu celular é de São Jorge": a propósito das religiões afro-brasileiras}

Provinda de camadas médias, eu nunca havia tido qualquer tipo de contato mais próximo com religiões afro-brasileiras, embora, obviamente, soubesse de sua existência. Assim, não suspeitava que as práticas relacionadas a essa crença religiosa pudessem ter ligação relevante com o meu 
tema de pesquisa. Entretanto, ao visitar os moradores em suas casas, percebi um objeto onipresente: um quadro com a imagem de São Jorge, geralmente logo acima da porta. Também notei muitos altares caseiros com imagens diversas. Além disso, logo descobri que a maior parte da família de Vânia, minha interlocutora evangélica, era umbandista: seus sete irmãos e suas irmãs, sua mãe e seus próprios filhos. Assim, percebendo o papel fundamental das religiões afro-brasileiras no morro $\mathrm{S}$. Jorge, passei a me perguntar se, como no caso dos evangélicos, os celulares teriam um papel na vivência religiosa de seus adeptos.

Foi no aniversário de dona Catarina, mãe de Vânia, que pude ter contato pela primeira vez com a umbanda. Como seu aniversário coincide com a data da festa de Cosme e Damião, no final de setembro, dona Catarina promove, à tarde, em sua casa, uma festa com distribuição de doces para as crianças no final. Nessa festa, os convidados, vestidos com roupas infantis, cantaram e dançaram ao som do tambor e "receberam" (entraram em transe e incorporaram) as "beijadas" (espíritos de crianças), que brincaram a tarde toda, tomando refrigerante em mamadeiras e se lambuzando com bolos confeitados. Durante o transe, notei um rapaz usando uma filmadora e algumas pessoas tirando fotos e filmando com seus celulares. A convite, comecei a frequentar alguns terreiros.

Três semanas depois, fui entrevistar Nena, membro de outra família com quem eu tinha contato. Nena é mãe solteira de dois filhos, de $10 \mathrm{e}$ 15 anos, e trabalha como auxiliar de limpeza. Tem vários namorados a quem constantemente pede presentes e se prostitui, às vezes, para conseguir uma renda extra. Na comunicação com "namorados" e "clientes", o celular é fundamental. Com Nena descobri que os telefones celulares entraram no circuito de bens que fazem parte do esquema de reciprocidade existente entre fiéis e suas "entidades" (espíritos, geralmente de escravos, que acompanham e são incorporados pelos praticantes). Nena diz que sua entidade é "da parte da 'esquerda', ela é mais pro mal que pro bem. Depende do que tu pedir pra ele. Se tu pedir pra cortar o pescoço de alguém, ele corta; se tu pedir pra te curar, ele te cura; se tu pedir um emprego, ele te dá". Nena queria um celular novo, mas teve de negociá-lo com sua entidade, que, em troca, quis um anel dourado: 
Aí eu pedi, eu quero um celular novo. Eu quero um celular "de flip". Só que ela não sabe o que é um celular, nem o que éflip, né, aí eu mentalizo ela e vou falando, vou perto da roupa dela e peço. Aí eu explico para ela, digo, "eu quero um que abre e fecha, assim". Aí... achei um, achei outro [...]. Na mesma semana ela botou cinco celulares na minha mão. Aí até que eu achei um que era parecido, mas ele não era de flip, era só a capinha dele. Aí eu disse não é esse que eu quero...! Isso foi acontecendo em uma semana, 15 dias. Aí eu dei um para o meu filho, outro eu "passei nos trocos". Tu vende, transforma tudo em comida para dentro de casa. Até que aí apareceu um beeeem bonitinho, pequeninho... Coisa mais fofinha ele era, desse tamanhinho assim, só que ele tinha antena. Mas achei. Aí fiquei contente.

Nena acredita que é preciso agradar as entidades constantemente, pois seu poder sobre a vida das pessoas é imenso - elas podem até interferir no funcionamento dos celulares. Nena me conta o que sua entidade pode fazer quando enraivecida: "Ele ligou para mim (um dos namorados) e eu não atendi. O telefone não tocou. E realmente tinha essa ligação. Mas porque 'ela' estava brava comigo, ela fez o telefone não tocar”. Outro namorado relutou em dar para Nena um celular mais moderno, com bluetooth: "Aí eu fui pro barracão e ela me disse que se eu desse uma coisa pra ela, ela fazia ele me dar o celular. E ele deu”. A entidade também é capaz de fazer Nena economizar seus créditos: "Quando eu quero muito falar com uma pessoa, eu vou lá nas coisas ‘dela' e peço para ela. Mentalizo bem a pessoa que eu quero falar e a pessoa acaba me ligando".

O espaço do terreiro é geralmente interdito aos celulares, especialmente para quem está "girando com o santo." É o que me asseveram um pai e uma mãe de santo com quem conversei. Em alguns terreiros do S. Jorge, os celulares devem ser colocados pelos filhos de santo, desligados, ao lado do peji (altar); em alguns, devem ficar no quartinho onde se veste a roupa "de santo" e são deixados os objetos pessoais; em outros, pode-se deixar o aparelho no silencioso. ${ }^{8}$ Nas sessões a que compareci,

${ }^{8}$ Essas diferenças se explicam pelo fato de que cada terreiro tem autonomia administrativa e ritual (PRANDI, 2005). 
vi, algumas vezes, praticantes com o celular no bolso, que checavam o aparelho nos intervalos. Entretanto, esquecimentos ocorrem, principalmente na "assistência" (plateia da sessão, que não está ali para "trabalhar com o santo"). Foi assim que descobri que os celulares podem incomodar até seres sobrenaturais como orixás, pretos velhos e outras entidades. Os celulares são denominados por esses seres espirituais de "grilos": "Geralmente, quando toca um celular, eles [as entidades] dizem 'ó, tem um grilo berrando’, e eles não gostam”, diz Nena. Marisa, outra iniciada na umbanda, explica: "É porque quebra a corrente de concentração e o orixá não vai vir". Marisa confirma que os celulares são "grilos" para as entidades, mas revela que há nomes alternativos: "O preto velho da minha mãe, ele diz que é 'taca-taca'. Também já ouvi chamarem de karé-karô, acho que é porque 'eles' ouvem o pessoal na assistência dizer "alô".

Entretanto, os namorados de Nena costumam ficar muito chateados quando ela não atende as ligações; querem sempre saber onde ela está. Certa feita, Nena me conta, "ligaram pra mim, eu estava com a entidade 'virada' [incorporada]. Depois que eu voltei em si, né, eu vi que tinha uma ligação perdida e liguei, aí a pessoa estava braba porque eu não atendi”. Por isso, Nena tenta negociar as tensões entre sua necessidade de estar disponível para os namorados e a entrada do celular na sessão, justificando que é a sua entidade que manda atender a chamada:

Porque às vezes... Como eu falei, eu tenho vários namorados. E tocou, eu estava com "ela", aí ela sabia que ia tocar, e mandou eu atender. Ela sabe de tudo. Eles chamam a gente de burra. Quer dizer, nós estamos na Terra e eles são um espírito, eles veem além. Aí a minha irmã foi e disse que eu tinha que falar com essa pessoa de qualquer jeito. Aí "ela" disse: 'pega o grilo que a coisa tá no grilo'. No caso, a coisa era o dinheiro, que tava no grilo. Aí o telefone tocou e a minha irmã atendeu e pediu para ele ligar mais tarde, que bem naquela hora eu não podia atender.

Outro ponto em que o celular é visto como mediador negativo é a captura de imagens. São muitos os adeptos que desejam ter uma imagem no celular que os mostre com a sua entidade incorporada, revela-me 
Natália, uma mãe de santo do candomblé. Segundo ela, algumas entidades até "gostam e fazem pose", mas outras, como os exus, "não gostam de foto nem de serem filmados. A minha [entidade] é raro, porque ou sai vermelho no meio ou sai preto... Eu fui ver agora na filmagem”. Não é incomum, no morro S. Jorge, que praticantes de distintas vertentes das religiões afro-brasileiras frequentem mais de um terreiro, como me explica Natália: "Várias religiões, os rituais são diferentes, candomblé, umbanda, Almas e Angola, jeje, batuque, só que a gente visita todas”. Para uma discussão mais aprofundada das similaridades e diferenças entre os rituais, assim como de suas dinâmicas atuais na interação com o ambiente urbano na contemporaneidade, vide, entre outros, Prandi (2005) e Silva (1995). Sebastiana, umbandista, diz que "alguns santos gostam de bater foto, principalmente quando é beijada, criança gosta de deixar bater foto". A entidade de Nena, por exemplo, odeia ser fotografada: "Se ela te ver com uma câmera na mão ela te vira as costas. Ela não se mostra pra ti, de jeito nenhum". Certa feita, seu sobrinho de 13 anos tirou uma foto de Nena com sua entidade incorporada, "e ele foi lá e mostrou para ela. E ela quase quebrou o celular, mandou apagar a foto, diz que ela fez o maior 'bafão' [escândalo]. Disse que só não ia quebrar ele porque ele trabalha para ela. Se ele não trabalhasse, ela quebrava ele todinho". Mas Nena acabou conseguindo a cobiçada foto, presenteando sua entidade com um par de brincos: "Ela sabia que eu queria a foto dela. Foi até nesse celular aqui, eu acho, mas eu acabei apagando sem querer”.

Ter uma representação visual da prática religiosa é importante para os umbandistas e candomblecistas, principalmente pelo caráter oral e visual dessas práticas religiosas. Os álbuns de fotos impressas são substituídos ou complementados com as fotos digitais, que são armazenadas no computador (os que têm) e no celular (caso da maioria). Ter imagens de sessões de umbanda no celular é tolerado pelas lideranças religiosas do S. Jorge devido ao caráter individual e privado dessa tecnologia. Entretanto, ouvi críticas de Vasco, um ogã, à publicação de sessões ou "giras" em geral em sites da internet como o YouTube: "É uma falta de respeito, qualquer um fica sabendo os segredos da nossa religião, tu 
vê gente 'girando com o santo' e tudo. Isso não acho certo, porque é importante o segredo na umbanda". Se não for possível ter sua foto "virado com o santo”, expressa-se a identidade religiosa através do uso de outras imagens. Foi o que observei em muitos celulares de adeptos: fotos dos filhos vestidos com "roupas de santo"; festas de santo nos terreiros; imagens de Iemanjá e de Cosme e Damião e, especialmente, o caso do “celular de São Jorge” (Figura 5). Explico: trata-se da prática de usar a imagem de São Jorge, ou Ogum, como papel de parede no celular. Como vimos, a imagem de São Jorge é extremamente popular na comunidade e está presente não apenas em quadros do santo nas casas, mas em camisetas, correntes usadas no pescoço e em tatuagens, como a que tem no braço um dos filhos de dona Catarina. "Meu celular é de São Jorge, de Ogum, porque ele é um protetor", assegura Sebastiana, que tem dois filhos iniciados que são ogãs - tocam atabaques e cantam nas sessões. O celular de Sebastiana foi o primeiro "celular de São Jorge" que vi; pude, posteriormente, fotografar mais alguns e soube da existência de vários outros. Foi Patrícia, filha de Sebastiana, que fotografou um quadro com a imagem de São Jorge para usar como papel de parede; depois, transferiu a imagem para o celular da mãe pelo bluetooth. "E enquanto esse celular tiver comigo, esse São Jorge fica aqui”, garante ela, que também usa uma corrente do santo. Rael, um experiente ogã de 30 anos de idade que é mentor de ogãs mais jovens, explica que é possível encontrar imagens de orixás na internet, mas é difícil porque "tem muito preconceito ainda em cima da umbanda”. Esse fator, aliado ao baixo acesso à internet na comunidade, pode explicar o surgimento da prática de captar imagens religiosas com celulares e distribuí-las via bluetooth.

SMS e bluetooth são duas funcionalidades importantes do celular na socialização de informações entre os umbandistas e candomblecistas do S. Jorge, principalmente os mais jovens. Pelas mensagens de texto, avisa-se, por exemplo, onde e quando haverá festas de santo ou quem tem uma foto boa de uma "gira" (sessão). O bluetooth, mais do que possibilitar uma renovada forma de expressão de identidade religiosa, como vimos, também desempenha um papel importante na obtenção 
e distribuição dos "pontos" - a música ritual da umbanda, dos quais há inúmeras variações. Segundo Natália, "É bom [ter celular com bluetooth] porque tem pontos novos que o pessoal não sabe, e aí passa um pro outro. Geralmente vem do Rio Grande do Sul, Rio de Janeiro". Seu amigo Rael - cujo toque de celular é um canto ritual em idioma iorubá - desde criança usava gravadores para registrar pontos novos e é quem está sempre atrás de novidades, obtidas, por vezes, na internet ou nos vários terreiros que visita e nos quais toca tambor. Rael avisa Natália por SMS quando há novidades de rezas e pontos, como ela me conta: "Porque assim, ó. Tem celular que dá e o que não dá. Como o meu já é pouco, o Rael grava e [...] manda a mensagem dizendo, olha, tem um ponto novo. Aí ele vem aqui em casa e a gente troca”. Nesse caso, como o celular de Natália não tem cartão de memória como o de Rael, ela passa os pontos para seu computador, que não acessa a internet (quando ela precisa usar, visita o irmão).

Natália já havia confirmado minha hipótese sobre o papel do celular na disseminação da música ritual, mas foi Rael quem me esclareceu sobre a presença do celular no treinamento dos ogãs adolescentes, reiterando, assim, outra hipótese de pesquisa. Muito embora um ogã se faça ritualmente, através do cumprimento de obrigações iniciáticas (PRANDI, 2005), o que observei no morro S. Jorge foi que o telefone celular auxilia informalmente no aumento do capital de conhecimento desses jovens filhos de santo. O ogã é o responsável por "segurar a gira" - são eles que "puxam os pontos", e devem fazê-lo com segurança e entusiasmo, contagiando os demais participantes. As giras são longas, podendo durar três horas (ou mais), e o ritual é todo cantado; as invocações aos orixás e santos católicos são mínimas. Saber a maior quantidade possível de pontos confere prestígio e é um sinal de experiência, diz, cheio de orgulho, Vasco, outro ogã experimentado: "Eu sei mais de 300 pontos de cor. Posso virar a noite na gira sem repetir nenhum”. Como há cada vez mais pontos hoje em dia, afirma Rael, "os ogãs ficam ouvindo os pontos no celular. Porque computador nem todos têm, e assim eles treinam em qualquer lugar. E eles vivem pegando pontos novos pelo bluetooth". 
Ao longo deste artigo, descrevi como a vivência da religiosidade afeta e é afetada pela inserção dos telefones celulares nas redes sociais da comunidade pesquisada. Argumentei que esses aparelhos são apropriados por evangélicos e umbandistas do morro S. Jorge de forma culturalmente significativa, objetificando valores de suas respectivas crenças religiosas. Tanto os membros da Assembleia de Deus quanto os adeptos de religiões afro-brasileiras ressignificam os usos dos telefones celulares em seu discurso e em suas práticas cotidianas levando em conta os preceitos e as características de suas crenças religiosas; desta forma, revestem o consumo de tecnologia de um sentido religioso.

Prandi (2005) afirma que, desde tempos remotos, as religiões se apresentam como eternas, mas, na verdade, estão sempre mudando para se adaptar aos novos constrangimentos sociais e culturais. Nesse sentido, espero que esta breve etnografia das práticas culturais, que explora as interseções entre religiosidade e consumo de tecnologia entre os habitantes do morro S. Jorge, possa contribuir para a discussão mais abrangente do lugar do sagrado na modernidade.

\section{Referências}

APPADURAI, A. Introduction: commodities and the politics of value. In; APPADURAI, A. The social life of things: commodities in cultural perspective. Cambridge: Cambridge University Press, 1986.

APPADURAI, A. Modernity at Large: cultural dimensions of globalization. Minessota: Minessota University Press, 1998.

BARZILAI-NAHON, K.; BARZILAI, G. Cultured technology: Internet and religious fundamentalism. Information Society, v. 21, n. 1, p. 25-40, 2005.

CAMPBELL, H. Texting the faith: religious users and cell phone culture. In: KAVOORI, A.; ARCENEAUX, N. (Orgs.). The cell phone reader: essays in social transformation. Nova York: Peter Lang Publishing, 2006.

MARIANO, R. Neopentecostais: sociologia do novo pentecostalismo no Brasil. São Paulo: Loyola, 1999.

MARIZ, C. L. Coping with poverty: pentecostals and christian base communities in Brazil. Filadélfia: Temple University Press, 1994. 
MILLER, D. Consumption as the vanguard of history: a polemic by way of an introduction. In: MILLER, D. Acknowledging Consumption (A Review of New Studies). Londres: Nova York: Routledge, 1995.

MILLER, D. Material culture and mass consumption. Oxford: Basil Blackwell, 1987. MILLER, D.; HORST, H. The Cell Phone: an Anthropology of Communication. Oxford; Berg, 2006.

PRANDI, R. Segredos guardados: orixás na alma brasileira. São Paulo: Companhia das Letras, 2005.

SILVA, V. G. Orixás da metrópole. Petrópolis, RJ: Vozes, 1995.

SILVA, S. R. Vivendo com celulares: identidade, corpo e sociabilidade nas culturas urbanas. In: BORELLI, S.; FREIRE FILHO, J. (orgs.). Culturas juvenis no século XXI. São Paulo: EDUC, 2008.

Data de submissão: 02/07/2015

Data de aceite: 22/10/2015 